\title{
Findriver- Driven Relationship among Shariah Compliant Indian and Indonesian Indices - An Empirical Evidence using Granger Causality
}

Badal Soni* and Sarthak Roy ${ }^{\dagger}$

\begin{abstract}
This paper attempts to establish the driver-driven relationship, co-integration, and causality relation between the Shariah indices of India and Indonesia. For this reason, two Indian Shariah indices, Nifty 500 and S\&P BSE 500 Shariah and two Indonesian Shariah indices IDX Shariah and Jakarta Islamic Index (JII) have been taken into consideration. A total of 1585 data points have been taken into account, and the period of the study is from May 2013 to October 2019 (approximately six years and six months). Empirical evidence of the study proves that there is reciprocity among the Shariah index of India, Nifty 500 Shariah, and S\&P BSE 500 Shariah. There exists no relationship between IDX Shariah and Jakarta Islamic Index when compared with Nifty 500 Shariah, individually. IDX Shariah is a driver index, though it is 11 years younger than Jakarta Islamic Index and, which is the driven index.
\end{abstract}

Keywords: Granger Causality, Shariah Indices, Linkages, Log Return, Reciprocity.

\section{Introduction}

In the recent past, Shariah, i.e., Islamic compliant, ethical, and socially responsible financing, has seen a staggering growth in

\footnotetext{
*Virginia Commonwealth University, USA; badalsoni78@gmail.com † Western Michigan University, USA; sarthakroy27@gmail.com
} 
prominent Muslim nations. As per Pew Research center (2015), Indonesia has the largest Muslim population (209.12 million) followed by India (176.2 million) and Pakistan (167.41 million) and hence while conducting a causality relationship test between Shariah of two-nation, it is imperative to study Shariah indices the top two Muslim populated countries.

Jakarta Islamic Index and IDX Shariah are the two popular Shariah indices of Indonesia. Jakarta Islamic Index was the first Islamic index of Indonesia and was launched on July 3, 2000. (Jakarta Islamic Index, n.d.) It primarily consists of 30 most liquid Islamic complaint stocks that are listed on IDX and ISSI. (ibid.) These stocks are selected on stock being a composition of ISSI and also maintained for the previous six months. Further screened based on the highest average ranking of Market capitalization for the past 12 months and then finally on the highest mean daily transaction value in the regular market. (ibid.) IDX Shariah (JKISSI) came into motion on May 13, 2011. It comprises of 407 stocks which follows the fatwa guidelines laid down by the fatwa national Shariah board in Indonesia. (IDX Shariah (JKISSI), n.d.)

Nifty 500 Shariah and BSE 500 Shariah are the two popular Shariah indices of India. Nifty 500 Shariah came into existence on February 19,2008 . It does not have a fixed number of companies. It currently comprises of 212 companies. For listing in this index, the stock should have been already listed for six months in nifty 500 and should be Shariah-compliant. This index is based on free-float market capitalization (Methodology Document of NIFTY50 Shariah Index NIFTY500 Shariah Index NIFTY Shariah 25 Index, n.d.) and a single stock cannot exceed the limit of $34 \%$ and cumulatively Top 3 stocks cannot exceed more than $63 \%$. (Nifty Indexogram, n.d.) This Index majorly includes sectors like Information technology $(31.22 \%)$, Consumer goods (29.22\%), and Energy (7.44\%), and so on and has major stakes are held by Infosys Ltd. (13.85\%), Tata Consultancy Services Ltd. (10.35\%) and Hindustan Unilever Ltd. $(6.65 \%)$ and so on.

S\&P BSE 500 SHARIAH index is weighted based on float-adjusted market capitalization. (S\&P BSE 500 SHARIAH Methodology, n.d.) It comprises 500 most massive, liquid stocks Trading on S\&P BSE 500 , which are Shariah-compliant, currently holding 261 companies 
(S\&P BSE 500 Shariah, n.d.) which represents 93\% of total market capitalization listed on BSE and also covers the major 20 industries of the country. It was a pioneering index to be partnered with S\&P Dow Jones Indices and BSE, which formed S\&P BSE 500 SHARIAH on February 19, 2013. (ibid.) But this came into existence on May 2, 2013. (ibid.)

The principle source of all Islamic thoughts is the Quran. All apprehension, including finance, finds it's roots in the Quran. As per, verse 275 Chapter of the Holy Quran, there are two types of contract, Al Bay (permissible) and Al Riba (Non-permissible) for people following Islamic religion. The primitive source of Shariah is the holy Quran and Sunnah. Secondary source (subject to the amendment but has to be approved by Shariah scholars) is also allowed, common ones are ijma (consensus among Shariah scholars and qiyas) arriving at inferences from an earlier state of affair, usually prophetic times. The third presumptive source is masalaha (public interest). The Shariah stock instills us with the knowledge of how to manage Islamic finance. The Shariah is postulated on aquidah, a set of rules and regulations between the human being and the almighty and this forms the crux for Islamic ideology which no room for any change and fiqh muamullah, lays down rules \& regulation regarding the transaction, i.e., the transaction must be physical asset-based and must have a beneficial outcome. The transaction that does not benefit and harm the society needs to be avoided, even if the transacting party personally gains. Shariah recognizes and protects for the property rights of the individual; it emphasizes one's obligation to society at large and the economic environment. Which is open for a difference of opinion and interpretation. (Bacha, Obiyathulla, and Mirakhor, 2018) Briefly, Shariah stocks are those stocks that follow the strict Islamic principle, which is said to be the most ethical and socially responsible investment avenue. (S\&P Shariah Indices Methodology, n.d.; Islamic Products, n.d.) Shariah-compliant indices prohibit the following:

1. Advertisement- advertisement for Tobacco, liquor, wager, and other non-Islamic activities.

2. Media and entertainment- distribution and broadcasting of movies, music, radio shows, TV shows with exception to 
news channels, kid's channels, news channels, sports channels, education channels, and newspapers.

3. Ribawi financial services like interest-based banking and interest-based finance company.

4. Investment in highly risky stocks, speculations, gambling, and profiting from one's ignorance.

5. Generating genetically alike individuals of an organism either naturally or artificially using cloning techniques.

6. Investment in Pornography, liquor, pork.

7. Hotels and restaurants providing non-halal products.

8. Trading on deferral basis and investment in gold and silver.

9. Investment in companies except which has Shariah committee to supervise all the activities, passes accountingbased screens have only Islamic products, and all investments are Islamic and so on.

In the recent past, many studies have shown a positive trend in Shariah-compliant indices. From this, many investors (mostly people who follow Islam and people who do not practice Islam) are likely to invest in Shariah-compliant stocks because it is the most ethical and socially more responsible investment avenue. So this detailed investigation attempts to study the driver-driven relationship and also extrapolate the future prices of the stocks of Indonesia and India and even the respective domestic indices.

\section{Objectives of Research}

1. To find out driver driven relationship between Shariah Indices of India and Indonesia.

2. To understand co-integration, dependence, linkages within the Shariah indices of the host countries and internationally among India and Indonesia. 


\section{Review of Literature}

Lately, an Indian research group (Verma, Anjali, \& Joseph, 2019) in their study, examined the causal relationship between the stock indices of western bloc countries in specific Belgium (BEL20) and France (CAC40). The period of the study is 1998 to 2018 on a day to day basis. The main objective of the researcher was to forecast the future time series data and relationships between the two indices. For this purpose, the Bivariate Granger Causality Test was used. The findings of the research were that both the index followed a free-float market capitalization weighting mechanism. It was found that a French index (CAC40) was dependent on the Belgium index (BEL20) despite being a much younger index. Before this, the same research group (Joseph, Tressa, \& Verma, 2018), in their paper discussed the causality relation as to which index is the driver and driven among the two Japanese indices NIKKIE (price-weighted leading blue-chip companies) and TOPIX (free-float adjusted market capitalization-weighted index). The period of the study is 20 years; the Bivariate Granger causality test is run on a logarithmic basis on the closing prices of both the index. The findings of the paper showed that NIKKIE (older index) was a driver index, and TOPIX (newer index) was a driven index that establishes the fact that more often than not, TOPIX is dependent upon NIKKIE index.

Another research team (Samadder, 2018), conducted a study to understand the long run and short-run linkages between Indian stock market and other indices of the developed nations including Australia, UK, USA, Canada, France and Germany, their study revealed the long term causality relation between India and US stock market, interestingly found that it would take a long time to arrive at equilibrium. It also found that in the short run France, Germany, and the USA stock were interlinked. The period of the study was 2nd January 2001 to 31st December 2016, and the tool for analysis was Johnsen Cointegration test.

(Ghosh and Srinivasan, 2013) With the help of existing people, they attempted to check the growth of Shariah investment in India. It also kept in mind that religious methods and the risk appetites in such investment vehicles differ from common western investment behaviors. The researcher used various procedures based on 
screening, such as sector-based screening, accounting based screening, and leverage compliance. It was found that Shariahcompliant stocks were having a better risk-return relationship than the rest.

Moreover, the returns of the Shariah indexes were different, even if the same methodology was used to select the stock. To conclude, the researcher stated that the Shariah funds are at its budding stage, and it is expected to grow over the years with recognition. Ghosh \& Srinivasan, (2015) in their research paper examined the rationale behind investment in CNX Shariah indices, whether it was sentimental driven or based on the rationale of investors. CNX Shariah adjusted closing prices have been taken on a daily basis, starting from $4^{\text {th }}$ March 2013 to 14th February 2014. Decision tree learning was used on CNX Shariah. The finding of the research shows that fewer sentiments weightage has been given by the investors while investing in CNX Shariah and valuation is given utmost importance while trading in CNX Shariah. Before this, Ghosh (2016), in his research studied the two Chinese bourse- Hang Seng and Shanghai stock exchange for a period of long 25 years to establish a causal relationship between the two Chinese indices and 6299 data points were taken into consideration. The researcher used the Johnsen Co-integration Test and the Bivariate Granger Causality test. The empirical evidence proved that Shanghai stock exchange was a driver index while Hang Seng index was a driven index.

To study the volatility of Shariah indices in Indian Capital Market Munusamy, Dharani, \& Narayanamoorthy (2015), analyzed the return on every Shariah stock. The team tested stationarity and autocorrelation using the Augmented Dickey-Fuller test and Q statistics. The research team observed that return series showing stationary at level and the existence of autocorrelation for all selected Shariah-compliant stocks. The key findings include a volatility clustering in the return series, the existence of Arch effect in the return series, and concludes that the volatility can be predicted in the Indian scenario. P, Natarajan \& M (2012) deeply studied the Shariah indices. The main motto of the study was to find the risk and return Shariah stocks and also to understand ethical investment in Shariah stocks. Hence, to establish the 
objective t-test, CAPM (to find beta) and correlation matrix were used. The findings proved that common stock and Shariahcompliant stock return and risk remained the same and hence concluded that Shariah complaint stock is a viable and an ethical investment avenue. Prior to this the same research group $(\mathrm{P}$, Natarajan \& M, 2011), examined the risk and return associated with the Nifty index and Nifty Shariah index for 4 years. The motto of the paper is to understand the performance of the Islamic index and the common index. The tools for analysis were the Sharpe index, Treynor Index, and Jensen alpha, apart from using the t-test to compute mean returns difference between both indices. The findings proved that Nifty Shariah was less volatile than the Nifty index, and both the indices performed similarly without much of deviations. On the similar lines, an attempt to study the linkage between Shariah-compliant stock, interdependency, establish a driver and driven relationship and to predict the future Shariah stocks Matharu (2019) used the Granger Causality to study the Shariah stocks, subject to the strict Islamic laws (the unchangeable divine law of god). Shariah is the most socially responsible investment in the world (Shariah, n.d.) The findings of the study proved that S \& P BSE 500 Shariah and Nifty Shariah 25 are based on Nifty 50 Shariah, and using nifty Shariah 50, the prices of Shariah stocks can be easily found out.

To understand and compare the risk and return between MSCI India Islamic index and MSCI Malaysia Islamic index (Habib, Mohsina and Islam, 2014) conducted a detailed investigation using standard deviation and beta calculation. The study for 11 years revealed that the Indian Islamic index has been on a lower side when compared to the performance of the Malaysian Islamic index. But during the crisis, both the indices have over-performed compared to their counterparts.

Ghosh and Srinivasan (2015) conducted a study to identify the driver and driven relationship among the BSE Sensex and CNX Nifty for a period ranging from 29th October 2013 to 18th august 2014 using Granger Causality Test as a tool to arrive at a conclusion that nifty though being a younger index drives the BSE Sensex and hence proved that there is no stochastic drift pattern and chances of arbitrage existed. 
Senthil, Arunachalam and Srividya (2014) From 2005 to 2014 identified the inter-linkage patterns between the stock markets of BSE Sensex and the Shanghai Composite Index. The researchers found out the 10-year month-end, closing logarithmic returns of the BSE Sensex and Shanghai Composite Index. The result showed that the Indian stock exchange is more receptive as compared to the Chinese stock exchange.

An Indian researching trio (Karim, Linn, \& Karim, 2017) had close research on the Islamic stock market and found out that the higher dispersion in the GDP and inflation leads to a more integrated stock market. The survey results of 10 countries, and it helped the Islamic stock markets to protect the inflation rate of the country. A lone Indian researcher (Mansoori , 2011) made an effort to figure out the legal terms of Islamic banks under Shariah. The research, by using the traditional Islamic laws and blending with modern Islamic finance, that the banks do not earn money by taking a colossal interest. It showed a positive inclination towards the assets rather than money.

Irfan (2016) figured out the relationship between the macroeconomic variables of India and the Islamic stock market. It came out to be true that different macro variables can be attributed with the help of the Islamic stock markets, and the Islamic stock market has a huge power to dominate the future market with its ethics and justice.

Saitia (2015) in his paper analysed the causal linkages in the daily returns among five ASEAN Shariah-compliant indices (such as FTSEMY index, MSSNGIL index, JAKSEIS index, MSTHFIL index, and MSPHISL index) through the application of the standard time series techniques. The motive of the research was to identify the extent of linkages of Islamic stock indices in five ASEAN countries. The methodology adopted to establish this was standard cointegration, long-run structural modeling, vector error correction, and variance decomposition technique, mainly using the Unit root test and Johansen's test. The key finding of the investigation was, in the long run, Malaysia Islamic Stock was a dominant market leader. The Jakarta Islamic Index is mostly the follower in the ranking list and is largely influenced by Islamic stock markets such as FTSEMY Malaysia Islamic Index and was a driving index. 
The Indian team consisting of Sheng, Andrew, and Singh (2013) stated in their research the usefulness of the lessons in the Islamic stock market for the architects and investors. The investors and architects should know about the long-term stocks and the complex literature of the share prices, respectively. They also stated the attraction by the equitable and stable conditions of the stocks in the market. Similarly, Tanwar, Sunita, and Irfan (2017) took the Shariah and non-Shariah indices and worked on the relationship between them with the respect of investors and industrial point of view. They proved that both the index were co-integrated. They also figured out that it had long-run equilibrium and were either bidirectional or directional.

\section{Methodology}

The researchers in this detailed investigation attempted to understand the reciprocity, inter-dependence of Shariah stock of Indonesia and India using Granger Causality as a tool to examine the same. The researchers choose a secondary source of data collection and are retrieved from www.investing.com and www.asiaindex.co.in. The log return of the Market Price of the indices is taken into consideration for this study.

Log return is the log difference between the current price and the initial price. (Miskolczi, 2017) The benefit of using log return in a time series data is that the data is normalized, and standard error is reduced. (Why Log Returns, 2011) Mainly Log return is used when the time period is very short, and the return is very minimal, and the investment avenue is less risky. (Log return, n.d.)

Reciprocity in layman's term means the give and take, mutualism, and collaboration between two parties or individuals. (Reciprocity, n.d.) Reciprocity means the co-integration, interdependence of on stock index over the other.

Example: If there exists reciprocity between two indices, then if one stock index underperforms, the other will also follow the same trend and vice-versa. This is known as reciprocity. 


\subsection{Development of Hypothesis}

\begin{tabular}{cl}
\hline S1 No. & \multicolumn{1}{c}{ Formulation of Hypothesis } \\
\hline 1. & $H_{0}:$ IDX Shariah does not Granger cause Nifty 500 Shariah. \\
& $H_{a}:$ IDX Shariah Granger cause Nifty 500 Shariah. \\
2. & $H_{0}:$ IDX Shariah does not Granger cause S\&P BSE 500 Shariah. \\
& $H_{a}:$ IDX Shariah Granger cause S\&P BSE 500 Shariah. \\
3. & $H_{0}:$ Nifty 500 Shariah does not Granger cause S\&P BSE 500 \\
& Shariah. \\
& $H_{a}:$ Nifty 500 Shariah Granger cause S\&P BSE 500 Shariah. \\
4. & $H_{0}:$ IDX Shariah does not Granger cause Jakarta Islamic Index. \\
& $H_{a}:$ IDX Shariah Granger cause Jakarta Islamic Index. \\
5. & $H_{0}:$ Jakarta Islamic Index does not Granger cause the S\&P BSE \\
& 500 Shariah. \\
& $H_{a}:$ Jakarta Islamic Index Granger cause S\&P BSE 500 Shariah. \\
6. & $H_{0}:$ Jakarta Islamic Index does not Granger cause Nifty 500 \\
& Shariah. \\
& $H_{a}:$ Jakarta Islamic Index Granger cause Nifty 500 Shariah.
\end{tabular}

Causality is always an apprehension in the minds of people; to find what led to a certain change in the phenomenon, or what brought changes. For example, whether the online marketing campaign increases customer loyalty, good offers, and discount led to an upsurge in website traffic, and hence, learning more about this subject matter is very crucial. There are broadly two classes- causal inference over random variables and causal inference over time series data. Causal inference over random variables represents two different events and causal inference overtime series, which determines who drives what and the extent to which it drives the other time-series data like aggregate daily closing stock prices and the volume.

A naïve interpretation of the results might suggest that there is a high level of correlation between $X$ and $Y$, or a degree to which $X$ drives $Y$ from a degree of $X^{\prime}$ s goodness as a prognosticator of $Y$. There are two approaches to causality, one is the classical statistical approach, and the other one is the adoptions and new approaches from various other researchers and dynamic systems.

In a deeper sense, causality can be divided into the following parameters (Palachy, n.d.)

1. Notions of Causality in time-series data 

a) Granger causality
b) Sims causality
c) Structural causality
d) Interventional causality

2. Classical methods for causality in time series data
a) Non-directional lagged interactions
b) Parametric VAR-based tests for Granger causality

3. Alternative parametric Granger causality for time series data are:
a) Conditional Granger Causality Index (CGCI)
b) MLP-based F-test for Granger causality
c) RBF models for Granger causality
d) Partial Granger Causality Index (PGCI)
e) Directed coherence measure

4. The alternative non-parametric causality measures for time series data are:
a) Bouezmarni-Taamouti test

5. Chaos and dynamic system theory approach for causality inference in time series data are:
a) The Hiemstra-Jones test
b) The Diks-Panchenko test
c) Convergent cross-mapping (CCM)
d) Extended Granger Causality Index (EGCI)

6. Information-theoretic approaches to causality inference in time series are:

a) Coarse-grained trans-information rate (CTIR)

b) Transfer entropy-based measures

c) Mutual Information from Mixed Embedding (MIME)

7. Graphical approaches for causality inference in time series are: 
a) Causal graph search algorithms (PC, SGS and FCI)

b) PCMCI

c) Lasso-Granger

d) Copula-Granger

e) Forward-Backward Lasso Granger (FBLG)

This study explores the causality relationship using Granger Causality. Granger causality is a statistical tool that primarily establishes the driver-driven relationship among two variables. Clive William John Granger first developed Granger Causality in the year 1969. (Granger Causality, n.d.) It is based on comparing the ability to predict a stochastic process $\mathrm{Y}$ using all the universe information denoted by $\mathrm{U}$, and using all data in $\mathrm{U}$ (except for some stochastic process $X$ ), it is denoted as $U \backslash X$. The main reason behind this is, removing $X$ reduces the predictive power with regards to $Y$, then $X$ contains exclusive information regarding $Y$, and hence $X$ Granger causes $Y$. Where $X$ and $Y$ are Stochastic stationary processes. Expressed with $\mathcal{U}_{\mathrm{i}}=\left(\mathrm{U}_{\mathrm{i}-1}, \ldots, \mathrm{U}_{\mathrm{i}_{-}} \infty\right)$ all information until time ' $\mathrm{i}$ '. The $\sigma^{2}\left(\mathrm{Y}_{\mathrm{i}} \mid \mathcal{U}_{\mathrm{i}}\right)$ the variance of the residual of predicting $\mathrm{Y}_{\mathrm{i}}$ using $\mathcal{U}_{\mathrm{i}}$ at time I and $\sigma^{2}\left(\mathrm{Y}_{\mathrm{i}} \mid \mathcal{U}_{\mathrm{i}} \backslash \mathcal{X}_{\mathrm{i}}\right)$ the variance of the residual of predicting $Y_{i}$ using all information in $\mathcal{U}_{\mathrm{i}}$ at time i except $\mathcal{X}_{\mathrm{i}}$.

1. If $\sigma^{2}\left(Y_{i} \mid U_{i}\right)<\sigma^{2}\left(Y_{i} \mid U_{i} \backslash X_{i}\right)$, then we say that $X$ Grangercauses $Y$, and write $X \Rightarrow Y$.

2. If $X \Rightarrow Y$ and $Y \Rightarrow X$, we say that feedback is occurring and write $X \Leftrightarrow Y$.

It is highly unrealistic to have access to all the information present in the universe, and hence $U$ is replaced with a limited set of time series data $X$, with $X \in \mathbf{X}$ and is read as $X$ granger causes $Y$ with respect to $X$.

The definition mentioned above does not specify the forecasting method used for $\sigma^{2}$, and hence allows both linear and non-linear models, but the variance used is to quantify the proximity of prediction restricts this notion of causality to causality in mean. This is referred to as strong Granger causality; the other notions of causality are Granger causality in mean and linear granger causality. (Hosoya, 1977) 
Instantaneous causality: It is a kind of marginally modified Granger causality. $X$ and $Y$ have instantaneous causality among them if, at time, ' $i$ ', summate $X_{i}$ to the information set helps to improve the accuracy in predict the value of $Y_{i}$. (Price, 1979) Where $X$ \& $Y$ are stationary stochastic processes. Expressed by $\mathcal{U}_{\mathrm{i}}=$ $\left(\mathrm{U}_{\mathrm{i}-1}, \ldots, \mathrm{U}_{\mathrm{i}-} \infty\right)$ which includes all the information in the universe up to time ' $\mathrm{i}$ ', and with $X_{\mathrm{i}}=\left(\mathrm{X}_{\mathrm{i}-1}, \ldots, \mathrm{X}_{\mathrm{i}} \quad-\infty\right)$ all information in $\mathrm{X}$ up to time 'i' (in both cases, not including information from time 'i' itself).

1. If $\sigma^{2}\left(Y_{i} \mid \mathrm{U}_{\mathrm{i}} \cup\left\{\mathrm{X}_{\mathrm{i}}\right\}\right)<\sigma^{2}\left(\mathrm{Y}_{\mathrm{i}} \mid \mathrm{U}_{\mathrm{i}}\right)$, then there is instantaneous causality between $X$ and $Y$. This type of causality is symmetric, but not directional and can be inferred from the above formulae that $\sigma^{2}\left(X_{i} \mid U_{i} \cup\left\{Y_{i}\right\}\right)<\sigma^{2}\left(X_{i} \mid U_{i}\right)$ (Lütkepohl, 2007) and thus, it cannot be said that $X$ instantaneously causes $Y$, but rather that there is instantaneous causality between $X$ and $Y$.

Multi-step causality: If in a bivariate system, the 1st step forecast for one variable can not be improved by using the information for the other variable, the same is true for all h-steps forecast for any $h=1,2, .$. and therefore the 1 step forward criteria is sufficient to define Granger causality. This result is no longer valid if additional variables are included in the information set. Hence, in a multivariate causality, $X_{i}$ is h-step causal for $Y_{i}$ if the information in $X_{i}$ helps improve the $j$-step forecasts of $Y_{i}$ for somej=1, 2,.., h. (Utkepohl, Helmut and Muller, 1994)

In simple layman's terms, Granger causality can be explained with an example of who is a leader and who is the follower. A total of 2617 data points is taken into consideration for a period ranging from $31 / 7 / 2009$ to $2 / 8 / 2019$. Granger causality is run on an online statistics and forecasting software- www.Wessa.net (Patric, 2019)

$$
\begin{aligned}
& X_{1}(t)=\sum_{j=1}^{p} A_{11 j} X_{1}(t-j)+\sum_{j=1}^{p} A_{12 j} X_{2}(t-j)+E_{1}(t) \\
& X_{2}(t)=\sum_{j=1}^{p} A_{21 j} X_{1}(t-j)+\sum_{j=1}^{p} A_{22 j} X_{2}(t-j)+E_{2}(t)
\end{aligned}
$$




\section{Results}

$X=$ IDX Shariah

$\mathrm{Y}=$ Nifty 500 Shariah

The results displayed explicitly deals with Indian (S\&P BSE 500 Shariah and Nifty 500 Shariah) and Indonesian (IDX Shariah and Jakarta Islamic Index) and their relationship. The cut- off for the study is maintained at $80 \%$ because this is a macro-economic study.

Granger Causality: Model 1: $\boldsymbol{y}=\boldsymbol{f}(\boldsymbol{x})$

\begin{tabular}{lcccccc}
\hline Model & $\begin{array}{c}\text { Residual } \\
\text { difference }\end{array}$ & $\begin{array}{c}\text { Diff. } \\
\text { DF }\end{array}$ & $\begin{array}{c}\text { F } \\
\text { value }\end{array}$ & $\begin{array}{c}\text { P } \\
\text { value }\end{array}$ & $\begin{array}{c}\text { Occurrence } \\
\text { (1-P-value) }\end{array}$ & $\begin{array}{c}\text { Remarks } \\
\text { (accept/ } \\
\text { reject }\end{array}$ \\
\hline $\begin{array}{l}\text { Complete } \\
\begin{array}{l}\text { Model } \\
\text { Reduced }\end{array}\end{array}$ & 1579 & & & & & \\
\begin{tabular}{l} 
Model \\
\hline
\end{tabular} & 1580 & -1 & 0.7317 & 0.3924 & $60.76 \%$ & REJECT \\
\hline
\end{tabular}

From the above table, it can found that the chance of occurrence of IDX Shariah is $60.76 \%$, and the cut off taken for the analysis is $80 \%$ \& hence, it is rejected.

Granger Causality: Model 2: $\boldsymbol{x}=\boldsymbol{f}(\boldsymbol{y})$

\begin{tabular}{lccccrc}
\hline Model & $\begin{array}{c}\text { Residual } \\
\text { difference }\end{array}$ & $\begin{array}{c}\text { Diff. } \\
\text { DF }\end{array}$ & $\begin{array}{c}\text { F } \\
\text { value }\end{array}$ & $\begin{array}{c}\text { P- } \\
\text { value }\end{array}$ & $\begin{array}{c}\text { Occurrence } \\
\text { (1-P-value) }\end{array}$ & $\begin{array}{c}\text { Remarks } \\
\text { (accept } \\
\text { / reject }\end{array}$ \\
\hline $\begin{array}{l}\text { Complete } \\
\begin{array}{l}\text { Model } \\
\text { Reduced } \\
\text { Model }\end{array}\end{array}$ & 1579 & & & & & \\
\hline
\end{tabular}

From the above table, the results show that the chance of occurrence of Nifty 500 Shariah is $14.71 \%$, and hence, it is rejected.

\subsection{Interpretation}

There is no relationship between IDX Shariah and Nifty 500 Shariah, and hence the Market prices cannot be used to predict the future prices of either of them and hence IDX Shariah, and Nifty 500 Shariah does not Granger cause each other. 
X= IDX Shariah

$\mathrm{Y}=$ S\&P BSE 500 Shariah

Granger Causality: Model 3: $\boldsymbol{y}=\boldsymbol{f}(\boldsymbol{x})$

\begin{tabular}{lcccccc}
\hline Model & $\begin{array}{c}\text { Residual } \\
\text { difference }\end{array}$ & $\begin{array}{c}\text { Diff. } \\
\text { DF }\end{array}$ & $\begin{array}{c}\text { F } \\
\text { value }\end{array}$ & $\begin{array}{c}\text { P- } \\
\text { value }\end{array}$ & $\begin{array}{c}\text { Occurre } \\
\text { nce } \\
(1-\mathrm{P}- \\
\text { value })\end{array}$ & $\begin{array}{c}\text { Remarks } \\
\text { (accept/ } \\
\text { reject }\end{array}$ \\
\hline $\begin{array}{l}\text { Complete } \\
\begin{array}{l}\text { Model } \\
\text { Reduced } \\
\text { Model }\end{array}\end{array}$ & 1579 & & & & & \\
\hline
\end{tabular}

From the above table, the results show that the chance of occurrence of IDX Shariah is $59.2 \%$, and hence, it is rejected.

Granger Causality: Model 4: $\boldsymbol{x}=\boldsymbol{f}(\boldsymbol{y})$

\begin{tabular}{lcccccc}
\hline Model & $\begin{array}{c}\text { Residual } \\
\text { difference }\end{array}$ & $\begin{array}{c}\text { Diff. } \\
\text { DF }\end{array}$ & $\begin{array}{c}\text { F- } \\
\text { value }\end{array}$ & $\begin{array}{c}\text { P- } \\
\text { value }\end{array}$ & $\begin{array}{c}\text { Occurrence } \\
\text { (1-P-value) }\end{array}$ & $\begin{array}{c}\text { Remarks } \\
\text { (accept/ } \\
\text { reject }\end{array}$ \\
\hline $\begin{array}{l}\text { Complete } \\
\text { Model }\end{array}$ & 1579 & & & & & \\
$\begin{array}{l}\text { Reduced } \\
\text { Model }\end{array}$ & 1580 & -1 & 2.3472 & 0.126 & $87.4 \%$ & Accept \\
\hline
\end{tabular}

From the above table, it found that the chance of occurrence of S\&P BSE 500 Nifty 500 Shariah is $87.4 \%$, and hence, it is accepted.

\subsection{Interpretation}

S\&P BSE 500 Shariah Granger causes IDX Shariah, and hence it is proved that the market prices of the S\&P BSE 500 can be used to predict the future market prices of IDX Shariah, and hence S\&P BSE 500 is the leader index and IDX Shariah is the follower index.

$X=$ Nifty 500 Shariah

$Y=S \& P$ BSE 500 
Granger Causality: Model 5: $\boldsymbol{y}=\boldsymbol{f}(\boldsymbol{x})$

\begin{tabular}{lcccccc}
\hline Model & $\begin{array}{c}\text { Residual } \\
\text { difference }\end{array}$ & $\begin{array}{c}\text { Diff. } \\
\text { DF }\end{array}$ & $\begin{array}{c}\text { F- } \\
\text { value }\end{array}$ & $\begin{array}{c}\text { P- } \\
\text { value }\end{array}$ & $\begin{array}{c}\text { Occurrence } \\
(1-\text { P-value })\end{array}$ & $\begin{array}{c}\text { Remarks } \\
\text { (accept/ } \\
\text { reject }\end{array}$ \\
\hline $\begin{array}{l}\text { Complete } \\
\begin{array}{l}\text { Model } \\
\text { Reduced } \\
\text { Model }\end{array}\end{array}$ & 1579 & & & & & \\
\hline
\end{tabular}

From the above table, the results prove that the chance of occurrence of Nifty 500 Shariah is $99.67 \%$, and hence it is accepted.

Granger Causality: Model 6: $x=\boldsymbol{f}(\boldsymbol{y})$

\begin{tabular}{|c|c|c|c|c|c|c|}
\hline Model & $\begin{array}{l}\text { Residual } \\
\text { difference }\end{array}$ & $\begin{array}{l}\text { Diff. } \\
\text { DF }\end{array}$ & F-value & P-value & $\begin{array}{l}\text { Occurrence } \\
\text { (1-P-value) }\end{array}$ & $\begin{array}{c}\text { Remarks } \\
\text { (accept/ } \\
\text { reject }\end{array}$ \\
\hline $\begin{array}{l}\text { Complete } \\
\text { Model }\end{array}$ & 1579 & & & & & \\
\hline $\begin{array}{l}\text { Reduced } \\
\text { Model }\end{array}$ & 1580 & -1 & 3.50386 & 0.0614 & $93.86 \%$ & Accept \\
\hline $\begin{array}{l}\text { From the } \\
\text { occurrenc } \\
\text { accepted. }\end{array}$ & $\begin{array}{l}\text { above ta } \\
\text { of S\&P }\end{array}$ & e, & an $b$ & aferre & $\begin{array}{l}\text { that the } \\
\% \% \text {, and }\end{array}$ & $\begin{array}{l}\text { nce of } \\
e \text { it is }\end{array}$ \\
\hline
\end{tabular}

\subsection{Interpretation}

There exists bi-directional causation, i.e., reciprocity between Nifty 500 Shariah and BSE 500 Shariah, which proves that both the index are closely integrated and they cause each other. This is because both are in the same domestic market (India) and have certain common stock and are subject to similar Regulation.

X=IDX Shariah

$\mathrm{Y}=$ Jakarta Islamic Index

Granger Causality: Model 7: $\boldsymbol{y}=\boldsymbol{f}(\boldsymbol{x})$

\begin{tabular}{lcccccc}
\hline Model & $\begin{array}{c}\text { Residual } \\
\text { difference }\end{array}$ & $\begin{array}{c}\text { Diff. } \\
\text { DF }\end{array}$ & $\begin{array}{c}\text { F- } \\
\text { value }\end{array}$ & $\begin{array}{c}\text { P- } \\
\text { value }\end{array}$ & $\begin{array}{c}\text { Occurrence } \\
(1-\text { P-value })\end{array}$ & $\begin{array}{c}\text { Remarks } \\
\text { (accept/ } \\
\text { reject }\end{array}$ \\
\hline $\begin{array}{l}\text { Complete } \\
\begin{array}{l}\text { Model } \\
\text { Reduced } \\
\text { Model }\end{array}\end{array}$ & 1579 & & & & & \\
\hline
\end{tabular}


From the above table, it is observed that the chance of occurrence of IDX Shariah is $93.71 \%$, and hence it is accepted.

Granger Causality: Model 8: $\boldsymbol{x}=\boldsymbol{f}(\boldsymbol{y})$

\begin{tabular}{lcccccc}
\hline Model & $\begin{array}{c}\text { Residual } \\
\text { difference }\end{array}$ & $\begin{array}{c}\text { Diff. } \\
\text { DF }\end{array}$ & $\begin{array}{c}\text { F- } \\
\text { value }\end{array}$ & $\begin{array}{c}\text { P- } \\
\text { value }\end{array}$ & $\begin{array}{c}\text { Occurrence } \\
\text { (1-P-value) }\end{array}$ & $\begin{array}{c}\text { Remarks } \\
\text { (accept/ } \\
\text { reject }\end{array}$ \\
\hline $\begin{array}{l}\text { Complete } \\
\begin{array}{l}\text { Model } \\
\text { Reduced } \\
\text { Model }\end{array}\end{array}$ & 1579 & & & & & \\
\hline
\end{tabular}

From the above table, the chance of occurrence of the Jakarta Islamic Index is $43.14 \%$, and hence it is rejected.

\subsection{Interpretation}

There exists a causality relationship between IDX Shariah and Jakarta Islamic Index. IDX Shariah is a stronger Index and contains information that can be used to predict the future prices of the Jakarta Islamic index.

$\mathrm{X}=$ Jakarta Islamic Index

$Y=$ S\&P BSE 500 Shariah

Granger Causality: Model 9: $\boldsymbol{y}=\boldsymbol{f}(\boldsymbol{x})$

\begin{tabular}{lcccccc}
\hline Model & $\begin{array}{c}\text { Residual } \\
\text { difference }\end{array}$ & $\begin{array}{c}\text { Diff. } \\
\text { DF }\end{array}$ & $\begin{array}{c}\text { F- } \\
\text { value }\end{array}$ & $\begin{array}{c}\text { P- } \\
\text { value }\end{array}$ & $\begin{array}{c}\text { Occurrence } \\
\text { (1- P-value) }\end{array}$ & $\begin{array}{c}\text { Remarks } \\
\text { (accept/ } \\
\text { reject }\end{array}$ \\
\hline $\begin{array}{l}\text { Complete } \\
\text { Model }\end{array}$ & 1579 & & & & & \\
$\begin{array}{l}\text { Reduced } \\
\text { Model }\end{array}$ & 1580 & -1 & 0.1944 & 0.6593 & $34.07 \%$ & Reject \\
\hline
\end{tabular}

From the above table, the chance of occurrence of the Jakarta Islamic index is $34.07 \%$, and hence it is rejected.

Granger Causality: Model 10: $x=\boldsymbol{f}(\boldsymbol{y})$

\begin{tabular}{lcccccc}
\hline Model & $\begin{array}{c}\text { Residual } \\
\text { difference }\end{array}$ & $\begin{array}{c}\text { Diff. } \\
\text { DF }\end{array}$ & $\begin{array}{c}\text { F- } \\
\text { value }\end{array}$ & $\begin{array}{c}\text { P- } \\
\text { value }\end{array}$ & $\begin{array}{c}\text { Occurrence } \\
(1-P \text {-value) }\end{array}$ & $\begin{array}{c}\text { Remarks } \\
\text { (accept/ } \\
\text { reject }\end{array}$ \\
\hline $\begin{array}{l}\text { Complete } \\
\text { Model } \\
\begin{array}{l}\text { Reduced } \\
\text { Model }\end{array}\end{array}$ & 1579 & & & & & \\
\hline
\end{tabular}


From the above table, it can be observed that the chance of occurrence of S\&P BSE Shariah is $88.97 \%$, and hence it is accepted.

\subsection{Interpretation}

S\&P BSE Shariah is the leading index, and the Jakarta Islamic Index is the following index, and hence, there exists a causality relationship between S\&P BSE Shariah and Jakarta Islamic index.

$X=$ Jakarta Islamic Index

$\mathrm{Y}=$ Nifty 500 Shariah

Granger Causality: Model 11: $\boldsymbol{y}=\boldsymbol{f}(\boldsymbol{x})$

\begin{tabular}{lcccccc}
\hline Model & $\begin{array}{c}\text { Residual } \\
\text { difference }\end{array}$ & $\begin{array}{c}\text { Diff. } \\
\text { DF }\end{array}$ & $\begin{array}{c}\text { F- } \\
\text { value }\end{array}$ & $\begin{array}{c}\text { P- } \\
\text { value }\end{array}$ & $\begin{array}{c}\text { Occurrence } \\
(1-\text { P-value })\end{array}$ & $\begin{array}{c}\text { Remarks } \\
\text { (accept/ } \\
\text { reject }\end{array}$ \\
\hline $\begin{array}{l}\text { Complete } \\
\begin{array}{l}\text { Model } \\
\text { Reduced } \\
\text { Model }\end{array}\end{array}$ & 1579 & & & & & \\
\hline
\end{tabular}

From the above table, the chance of occurrence of the Jakarta Islamic Index is $64.57 \%$, and hence, it is rejected.]

Granger Causality: Model 12: $x=\boldsymbol{f}(\boldsymbol{y})$

\begin{tabular}{lcccccc}
\hline Model & $\begin{array}{c}\text { Residual } \\
\text { difference }\end{array}$ & $\begin{array}{c}\text { Diff. } \\
\text { DF }\end{array}$ & $\begin{array}{c}\text { F- } \\
\text { value }\end{array}$ & $\begin{array}{c}\text { P- } \\
\text { value }\end{array}$ & $\begin{array}{c}\text { Occurrence } \\
\text { (1-P-value) }\end{array}$ & $\begin{array}{c}\text { Remarks } \\
\text { (accept/ } \\
\text { reject }\end{array}$ \\
\hline $\begin{array}{l}\text { Complete } \\
\begin{array}{l}\text { Model } \\
\text { Reduced } \\
\text { Model }\end{array}\end{array}$ & 1579 & & & & & \\
\hline
\end{tabular}

From the above table, it is found that the chance of occurrence of Nifty 500 Shariah is $12.8 \%$, and hence, it is rejected.

\subsection{Interpretation}

There exists no relationship between the Jakarta Islamic index and Nifty 500 Shariah. Both the index are independent of each other, and hence, there exists no causal relation between the two. 


\section{Conclusion}

In the detailed investigation, it was found that there exists no relationship between IDX Shariah and Nifty 500 Shariah and, Jakarta Islamic Index and Nifty 500 Shariah hence the Market prices of cannot be used to predict the future prices of either of them and hence these indices do not Granger cause each other. The reason behind this is, Nifty 500 Shariah is an Indian index while IDX Shariah and Jakarta Islamic Index are Indonesian indices, and they do not have common stocks or common law governing the indices. Moreover, the macro-economic factors in both countries are different.

On the contrary, there exists a causality relationship between S\&P BSE Shariah and IDX Shariah, and S\&P BSE Shariah and Jakarta Islamic Index, though they are international Indices because of certain commonalities or ties between the countries like bilateral trade agreement, member of G-20, the E-7 (countries), nonalignment movement, member of ASEAN and the UN. (India and Indonesia relations, n.d.)

In the ASEAN region, Indonesia has emerged as the second-largest partner of India. From 2005-2006 to 2018-19, the bilateral trade has almost five times, i.e., from USD $4.3 \mathrm{bn}$ to USD $21 \mathrm{bn}$. India is the second-largest importer of coal and crude palm oil from Indonesia. It also imports minerals, pulp, rubber, paper, and hydrocarbons reserves.

On contrary Indonesia, imports refined petroleum products, commercial vehicles, telecommunication equipment, agriculture commodities, plastic, bovine meat, and steel products. There are 30 Indian joint ventures in Indonesia. The Indian investment in Indonesia is USD $995.18 \mathrm{mn}$ in about 2215 ventures between 2000 to 2018. On the contrary, Indonesia has invested USD $629.16 \mathrm{mn}$ between 2000 to 2019. (India-Indonesia Bilateral Brief, n.d.)

There exists reciprocity between Nifty 500 Shariah and BSE 500 Shariah, which means that the indices are closely integrated, and they cause each other, this is because both are in the same domestic market (India) and have certain common stock and are subject to 
similar Islamic regulations. But Nifty 500 Shariah slightly has the edge over the BSE 500 Shariah with $99.67 \%$ chance of occurrence.

In Indonesia, IDX Shariah is a stronger Index and contains information that can be used to predict the future prices of the Jakarta Islamic Index, and IDX Shariah is the driver index, and Jakarta Islamic Index is then driven index. The fascinating part is that, though and Jakarta Islamic Index is was found much earlier and is the oldest Shariah index in Indonesia, it is following IDX Shariah that was found in 2011.

\subsection{Application}

The investment in Shariah-compliant indices has seen incredible growth in the recent past, and the researchers predict the same trend to continue looking at the increasing Muslim population, especially in India and Indonesia. (Pew Research center, 2015) By 2050 India $(31,06,60,000)$ will lead the Muslim population in the world followed by Pakistan $(27,31,10,000)$ and further followed by Indonesia $(25,68,20,000)$. Hence the findings of this research can be used by both Islam and non-Islam investors while taking an investment decision in these indices. This can also be used by Arbitrageurs when the stocks are trading in two different markets or index. This paper can be used by foreign institutional investors (FII), High Net worth individuals (HNI), Qualifies Institutional Buyers (QIB) for taking a rationale investment decision, deciding the portfolio, and to sum up, will be helpful in better decisions making.

\subsection{Limitations}

1. The study does not include all the Shariah Indices of both the countries, India and Indonesia.

2. The Time-horizon of the study is six years and 6 months, starting from May 2013 to October 2019.

\section{References}

Bacha, O., \& Mirakhor, A. (2018). Islamic capital market: A comparative approach (2nd ed.). Singapore: World Scientific Publishing Co. Pte. Ltd. 
Ghosh, B., \& Srinivasan, P. (2015). Rationale of investing to re-script the India story- A case on CNX Shariah. Re Scripting India's Growth Story CMS B School Jain University Bangalore. Retrieved from https://www.researchgate.net/publication/277775179_Rationale_of_ Investing_to_re-script_the_India_Story-_A_case_on_CNX_Sharia

Ghosh, B., \& Srinivasan, P. (2013). Shariah Investment in India: An Unexplored Opportunity. International Journal of Innovative Research $\mathcal{E}$ Development, 2(12),33-37. Retrieved from https:// www.researchgate.net/publication/265251564_Shariah_Investment_i n_India_An_Unexplored_Opportunity

Ghosh, B., \& Srinivasan, P. (2015). A Statistical Analysis of the Stochastic Drift between Sensex \& Nifty- an in-Depth Study. International Journal of Innovative Research $\mathcal{E}$ Development, 4(5), 12. Retrieved from https://www.researchgate.net/publication/276849506_A_Statistical_ Analysis_of_the_Stochastic_Drift_between_Sensex_Nifty-_an_inDepth_Study

Ghosh, B. (2016). Do the Dragons Move Together; Co-integrated and causality study among Chinese bourses-A curious case of Hang Seng and Shanghai Stock Exchange. Al-Barkaat Journal of Finance $\mathcal{E}$ Management, 8(2), 1-8.

Granger Causality. (n.d.). Retrieved from https:// en.wikipedia.org/ wiki/Granger_causality

Habib, M., \& Islam, K. (2014). Performance of Shariah Compliant Index: A Comparative Study of India and Malaysia. International Journal of Interdisciplinary and Multidisciplinary Studies (IJIMS), 1(6), 231-241. Retrieved from https://www.researchgate.net/ publication/ 316654788_Performance_of_Shariah_Compliant_Index_A

_Comparative_Study_of_India_and_Malaysia

IDX Shariah (JKISSI). (n.d.). Retrieved October 31, 2019, from https://www.investing.com/indices/idx-Shariah

Irfan, M. (2016). A Study of Islamic Stock Indices and Macroeconomic Variables. International Journal of Economics and Management Engineering, 10(7), 2553-2561. Retrieved from https:// waset.org/ publications/10006075/a-study-of-islamic-stock-indices-andmacroeconomic-variables

Islamic Products. (n.d.). Retrieved October 31, 2019, from https://www.idx.co.id/en-us/idx-islamic/islamic-product/

Islamic Stock Index. (n.d.). Retrieved October 31, 2019, from https://www.idx.co.id/en-us/idx-islamic/islamic-stock-index/

Jakarta Islamic (JII). (n.d.). Retrieved October 31, 2019, from https://in.investing.com/indices/idx-islamic

Jakarta Islamic Index. (n.d.). Retrieved October 31, 2019, from https://en.wikipedia.org/wiki/Jakarta_Islamic_Index 
Joseph, T., \& Verma, A. (2018). Driver-Driven relationship between the Tokyo Stock Exchange Indices- TOPIX and NIKKIE. Asian Journal of Management, 9(4).

Karim, B., Linn, J., \& Karim, Z. (2017). Determinants of the Islamic Stock Markets Integration. Accounting and Finance Research, 6(3), 147-152.

Log return. (n.d.). Retrieved November 4, 2019, from Princeton University website: https://orfe.princeton.edu/ jqfan/fan/FinEcon/chap1.pdf

Matharu, T. (2019). Interlinking the Shariah-Compliant Stocks in India: An Analysis Using Granger Causality. Ushus-Journal of Business Management, 18(3), 39-49.

Methodology document of nifty 50 Shariah index nifty 500 Shariah index nifty Shariah 25 index. (n.d.).

Panna, M. (2017). Note on simple and logarithmic return. APSTRACT: Applied Studies in Agribusiness and Commerce, 11(1033-2017-2935), 127136.

2Mansoori, M. T. (2011). Is" Islamic Banking" Islamic? Analysis of current debate on Sharīah legitimacy of Islamic banking and finance. Islamic Studies, 383-411.

Dharani, M., Narayanamoorthy, V., \& Natarajan, P. (2015). An Empirical Study on Volatility Pattern of the Shariah Compliant Stocks in Indian Capital Market. Journal of Economic Policy and Research, 10(2), 150-165.

Nifty Indexogram. (n.d.). https://www.niftyindices.com/ Factsheet/ Factsheet_Nifty500_Shariah.pdf

Munusamy, D., \& Natarajan, P. (2011). Equanimity of risk and return relationship between Shariah index and general index in India. Journal of Economics and Behavioral Studies (JEBS), 2(5), 213-222.

Natarajan, P., \& Dharani, M. (2012). Shariah Compliant Stocks in India: A Viable and Ethical Investment Vehicle. Oman Chapter of Arabian Journal of Business and Management Review, 34(953), 1-13.

Patric, W. (2019). Free Statistics Software, Office for Research Development and Education. Retrieved from https:// www.wessa.net/

Pew Research center. (2015). 10 Countries with the Largest Muslim Populations, 2010 and 2050. Retrieved from https:// www.pewforum.org/2015/04/02/muslims/pf_15-0402_projectionstables74/

S\&P BSE 500 Shariah. (n.d.). Retrieved October 31, 2019, from https://www.asiaindex.co.in/indices/equity/sp-bse-500-Shariah

S\&P BSE 500 Shariah Index. (n.d.). Retrieved October 31, 2019, from https://en.wikipedia.org/wiki/S\%26P_BSE_500_Shariah_Index

S\&P BSE 500 SHARIAH Methodology. (n.d.). Retrieved from file:///C:/Users/Admin/Downloads/methodology-sp-bse-500Shariah-indices.pdf 
S\&P Shariah Indices Methodology. (n.d.). Retrieved from file:///C:/ Users/Admin/Downloads/methodology-sp-Shariah-indices.pdf

Samadder, S., \& Bhunia, A. (2018). Integration between Indian Stock Market and Developed Stock Markets. Journal of Commerce and Accounting Research, 7(1), 13.

Kumar, A. S., \& Srividya, V. (2014). Stock Market Interlinkages among the Two Largest Emerging Economies of Asia--The Case of India and China. International Journal of Economic Perspectives, 8(4).

Shariah. (n.d.). Retrieved September 20, 2019, from https:// en.wikipedia.org/wiki/Sharia

Sheng, A., \& Singh, A. (2013). Islamic stock markets in a global context. Economic development and Islamic finance, 275.

Irfan, M., \& Tanwar, S. Are Shariah and Non-Shariah Indices Related? Some Empirical Evidence from India. IOSR Journal of Business and Management (IOSR-JBM), 19(7).

Verma, A., \& Treesa Joseph, T. The Causal Relationship between the Stock Indices of Western Bloc Countries: A Case on Belgium and France. Ushus- Journal of Business Management, 18(3), 25-38.

Why Log Returns. (2011). Retrieved November 4, 2019, from https:/ / quantivity.wordpress.com/2011/02/21/why-log-returns/I

India-Indonesia Bilateral Brief. (n.d.). Retrieved November 10, 2019, from Ministry of external affairs website: https:// mea.gov.in/ Portal/ ForeignRelation/Ind_Indonesia_N_2019.pdf

India and Indonesia relations. (n.d.). Retrieved November 10, 2019, from https://en.wikipedia.org/wiki/India-Indonesia_relations

Reciprocity. (n.d.). Retrieved September 20, 2019, from https:// en.wikipedia.org/wiki/Reciprocity_(network_science)

Saitia, B. (2015). Cointegration of Islamic Stock Indices: Evidence from Five ASEAN Countries. International Journal of Scientific $\mathcal{E}$ Engineering Research, 6(7), 1392-1405.

Hosoya, Y. (1977). On the Granger Condition for Non-Causality. Econometrica, Econometric Society, 45(7), 1735-1736.

Lütkepohl, H. (2007). New Introduction to Multiple Time Series Analysis. Springer Berlin Heidelberg.

Palachy, S. (n.d.). Inferring causality in time series data. Retrieved November 16, 2019, https://towardsdatascience.com/inferringcausality-in-time-series-data-b8b75fe52c46

Price, M. (1979). The characterization of instantaneous causality: A correction. Journal of Econometrics,10(2),253-256.

Utkepohl, Helmut, and Muller, M. (1994). Testing for Multi\{Step Causality in Time Series. http://citeseerx.ist.psu.edu/ viewdoc/ download; jsessionid=9B54CB35E4F3AA6576B763E1DCFC5056?doi=10.1.1.45.342 $0 \&$ rep $=$ rep $1 \&$ type $=$ pdf 